\title{
Population dynamics of an intertidal 0-group flounder Platichthys flesus population in the western Dutch Wadden Sea
}

\author{
Henk W. van der Veer, Magda J. N. Bergman, Rob Dapper, Johannes IJ. Witte
}

Netherlands Institute for Sea Research (NIOZ), PO Box 59, 1790 AB Den Burg Texel, The Netherlands

\begin{abstract}
Larval immigration and subsequent settlement, abundance fluctuations, growth, and mortality of a 0 -group flounder population were studied in a tidal flat area, the Balgzand, in the western Wadden Sea. Larvae entered the area from early April to early May. The first settled flounder were found about 1 mo after larval immigration started. Settled flounder were restricted to the siltier areas of the tidal flats. Growth did not seem to be food-limited within the density range observed over the years and depended only on prevailing water temperatures. The life history pattern of flounder was similar to that of plaice in the same area: year-class strength was generated in the open sea and after settlement a period of density-dependent mortality followed, most probably due to predation by crustaceans. The instantaneous mortality rate $Z$ during summer seemed to be higher $\left(008 \mathrm{~d}^{-1}\right)$ than in plaice $\left(0.03 \mathrm{~d}^{-1}\right)$, probably due to a combination of higher water temperature and higher abundance of predators in summer than during the settlement of plaice in spring. No relationship between the year-class strengths of plaice and flounder was found
\end{abstract}

\section{INTRODUCTION}

Over the last decades plaice Pleuronectes platessa L. has been studied in detail in the western Dutch Wadden Sea. This research concentrated especially on the recruitment mechanisms of plaice during its juvenile stage in the coastal nursery areas, where the larvae settle and spend their first years of life (Zijlstra 1972, Kuipers 1973, 1977, Creutzberg et al. 1978, Rauck \& Zijlstra 1978, Zijlstra et al. 1982, Rijnsdorp et al. 1985, van der Veer 1985, 1986, Zijlstra \& Witte 1985, van der Veer \& Bergman 1986, 1987, Bergman et al. 1988, 1989, van der Veer et al. 1990). The main conclusions of this research were: (1) The year-class strength of plaice is generated during the pelagic egg or larval stages (van der Veer 1986). (2) In spite of the high concentrations of juveniles in relatively small nursery areas and the fluctuations in density between years, food conditions are always optimal for the major part of the population (Zijlstra et al. 1982, van der Veer 1986, Bergman et al. 1987, 1988, van der Veer et al. 1990). (3) Mortality rates during the juvenile stages are low compared to other fish species due to the absence of most potential predators in the sheltered nursery areas (van der Veer et al. 1990). Variability in recruitment to the parent stock is low (van der Veer 1986, van der Veer \& Bergman 1987), as a result of a period of density-dependent mortality caused by the brown shrimp Crangon crangon in at least the main nursery of plaice, the Wadden Sea.

It is feasible to test whether the above conclusions apply also to the flounder Platichthys flesus L., another common flatfish species in the western Wadden Sea (de Vlas 1979). Its life cycle resembles that of plaice. Spawning areas are also located in the open North Sea, and they overlap with those of plaice (Harding et al. 1978). As in plaice, large quantities of small larvae from the North Sea immigrate into the Wadden Sea every year (van der Veer 1985). After immigration, settling in the area occurs (de Vlas 1979). Due to a strong rheotaxis behaviour (Berghahn 1984), settling of larvae has only been observed in the siltier parts of the Wadden Sea (de Vlas 1979), especially near freshwater inlets (Berghahn 1984). Large parts of the settling flounder population are thought to migrate to fresh water (Berghahn 1984), and only part of the population remains in the estuary. Flounder apparently remain in the Wadden Sea for much longer than 3 yr (de Vlas 1979); then they emigrate to deeper waters. While plaice larvae immigrate in March and April, flounder larvae are only found in April (van der Veer 1985). As a 
consequence, settlement and growth of flounder start later in the season.

This paper summarizes information on immigration and settlement of pelagic larvae and abundance of 0 group flounder in an intertidal flat area in the western Dutch Wadden Sea, the Balgzand. Distribution, growth, mortality rates and mortality factors of settled flounder are examined and compared with those found for 0-group plaice in the area.

\section{MATERIAL AND METHODS}

Study area. The intertidal Balgzand has an area of about $52 \mathrm{~km}^{2}$ (Fig. 1); it is surrounded by dikes to the south and west and otherwise by 5 to $20 \mathrm{~m}$ deep tidal channels. Most of the area consists of barren tidal flats with only a few mussel beds in the northwestern part. Sediment composition of the flats varies from coarse sand in the exposed northern part to fine sands and mud in the sheltered southern areas (Dapper \& van der Veer 1981). Median grain size is about $150 \mu \mathrm{m}$ and mean silt content is about $5 \%$. For 8 to $10 \mathrm{~h}$ of the tidal cycle the flats are submerged and for 2 to $4 \mathrm{~h}$ they are exposed. At high water the water depth varies between

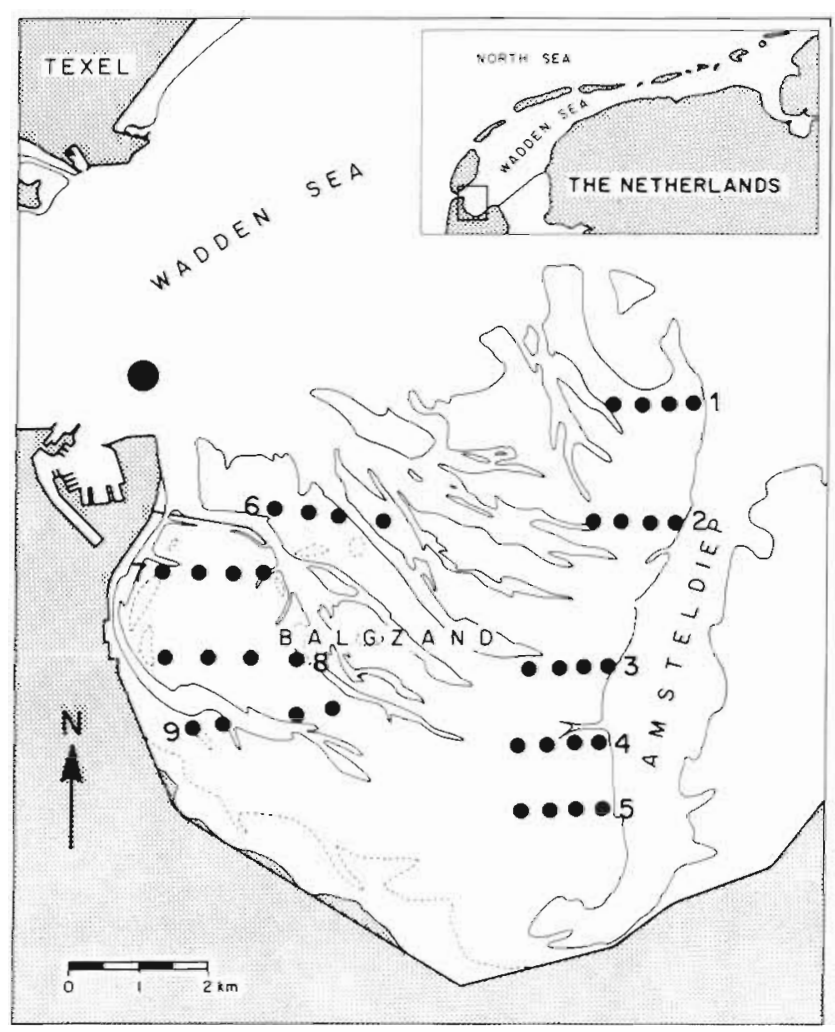

Fig 1 Location of the Balgzand tidal flat area in the western Wadden Sea (O) Pelagic sampling station in the Marsdiep inlet, (-) demersal samplung stations
0.8 and $1.5 \mathrm{~m}$, the actual depth depending on prevailing weather conditions. The flats are intersected by numerous small gullies through which the water recedes to the deeper tidal channels during the later phase of the ebb tide.

Plankton sampling. Plankton sampling was carried out from 1979 to 1986 in the deep Marsdiep tidal inlet. Each year 4 to 6 surveys of 1 wk were conducted. Only the midwater stratum (depth 7 to $10 \mathrm{~m}$ ) was sampled with a net of $14 \mathrm{~m}$ length, an opening of $3.1 \mathrm{~m}^{2}$, a mesh size of $1.4 \mathrm{~mm}$ and a filtration area of $51 \mathrm{~m}^{2}$ (definitions according to Smith et al. 1968). Haul duration was $45 \mathrm{~min}$. For more details see Creutzberg et al. (1978) and Rijnsdorp et al. (1985).

All matenal was preserved in a $4 \%$ formaldehyde seawater solution and sorted out in the laboratory. Flounder larvae were measured to the nearest mm total length within $3 \mathrm{mo}$. No correction was made for net efficiency, since a comparison of day and night catches did not suggest an increase in net avoidance with length (van der Veer 1985). For each haul, numbers caught were converted into densities per $1000 \mathrm{~m}^{3}$ ( $\mathrm{n} 1000 \mathrm{~m}^{-3}$ ) and the arithmetic mean was estimated per sampling date.

The variance consistently surpassed the arithmetic mean, indicating a contagious distribution of the larvae. Confidence limits for such distributions can be computed by using the factors from a logarithmic $(x+1)$ transformation and applying them to the arithmetic mean of the samples (Elliot 1971). For the $95 \%$ confidence limits these factors of the Student's $t$-distribution range between 2.09 and 2.02 , depending on the numbers of hauls made (20 to 40 ). Therefore, the $95 \%$ confidence limits would lie between 47 and $209 \%$ of the mean.

Demersal sampling. Demersal sampling was originally desıgned for 0-group plaice (Zijlstra et al. 1982, van der Veer 1986) and consisted of a grid of 36 stations distributed over the Balgzand area (Fig. 1). Sampling was carried out at fixed time intervals between February and October in 1976 to 1982. The fishing gear used was a $1.9 \mathrm{~m}$ beam-trawl (mesh size $5 \times 5 \mathrm{~mm}$ ) towed by a rubber dinghy with a $25 \mathrm{hp}$ outboard motor at a speed of ca $35 \mathrm{~m} \mathrm{~min}^{-1}$, according to Riley \& Corlett (1966). Sampling was restructed to a period of $3 \mathrm{~h}$ around high water durng the day, when the distribution of flatfish appeared to be random on the tidal flats (Kuipers 1977). The length of a haul was assessed with a meter wheel fitted outside the trawl. Each haul sampled a surface area of at least $200 \mathrm{~m}^{2}$ All material was preserved in $4 \%$ formalun seawater solution and sorted out within a few days From 1979 onwards, flounder were measured to the nearest $\mathrm{mm}$ total length class. All numbers caught were corrected for net efficiency, using the plaice data after Kupers (1975) and Dapper (1978). 
The corrected numbers were converted into densities per $1000 \mathrm{~m}^{2}$ (n $1000 \mathrm{~m}^{-2}$ ) and the arithmetic mean was calculated for each survey as an index of abundance for the population on the tidal flats at high water. To assess confidence limits of the mean, a number of surveys should be carried out simultaneously, but such data are lacking. Instead, the method developed by Zijlstra et al. (1982) for 0-group plaice was applied. Estimated confidence limits were based on the variation in mean abundance from July onwards, when the population had stabilized. The $95 \%$ confidence limits obtained by this method were estimated at about $45 \%$ of the mean. Statistical treatment of the data sets was restricted to Spearman rank correlation test. Since the various sampling programmes were not always carried out simultaneously, the different tests are based on varying numbers of observations (year).

Predation experiment. Predation experiments with brown shrimps Crangon crangon as predators and small 0-group flounder as prey were carried out similarly to the experimental set-up designed by van der Veer \& Bergman (1987) for 0-group plaice. In the field the importance of shrimp predation on settled flounder was traced by examining fin damage among the 0 group flounder, indicating unsuccessful predation attempts by Crangon crangon (van der Veer \& Bergman 1987).

\section{RESULTS}

\section{Plankton data}

Table 1 shows the mean flood abundance of flounder larvae during the period of immigration for the different years. This period of larval immigration is defined
Table 1. Platichthys flesus. Mean flood abundance of flounder larvae in the deep Marsdiep tidal inlet during the period of larval immigration (see text and Fig. 1)

\begin{tabular}{|cc|}
\hline Year & Abundance $\left(\mathrm{n} 1000 \mathrm{~m}^{-3}\right)$ \\
\hline 1974 & 0.2 \\
1975 & 11.9 \\
1977 & 6.9 \\
1980 & 8 \\
1981 & 13 \\
1982 & 7 \\
1983 & 2.8 \\
1985 & 37.4 \\
1986 & 6.0 \\
\hline
\end{tabular}

as the time span between the first and last week when flounder larvae were caught in the plankton during flood tide. The mean weekly catches during that period were averaged and used as mean abundance over the whole period of immigration. Large differences in yearclass strength between years were observed at the end of the larval stage: from $0.21000 \mathrm{~m}^{-3}$ in 1974 to 37.4 $1000 \mathrm{~m}^{-3}$ in 1985 . The first larvae appeared in the plankton in early April and they remained present until the beginning of May.

\section{Demersal surveys}

0-group flounder were absent at the northernmost sampling stations, both in the eastern and western parts of the area (Fig. 1; Transects 1, 2, 3 and 6). They were found in areas with a medium-sized sediment composition or in muddy areas (for sediment composition see Dapper \& van der Veer 1981). Fig. 2 shows the
Fig. 2. Platichthys flesus. Abundance of 0 -group flounder (n $1000 \mathrm{~m}^{-2}$ ) on the Balgzand in 1974 to 1982 , mean values of Transects $4,5,7,8$ and 9 (see Fig. 1).

$(\bullet--\bullet) 1975 ;(0---0) 1976$

$(\triangle \longrightarrow \triangle)$ 1977; (ロ- D) 1978

(-D) $1979 ;(\diamond \cdot$ - ○) 1980

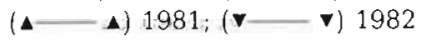

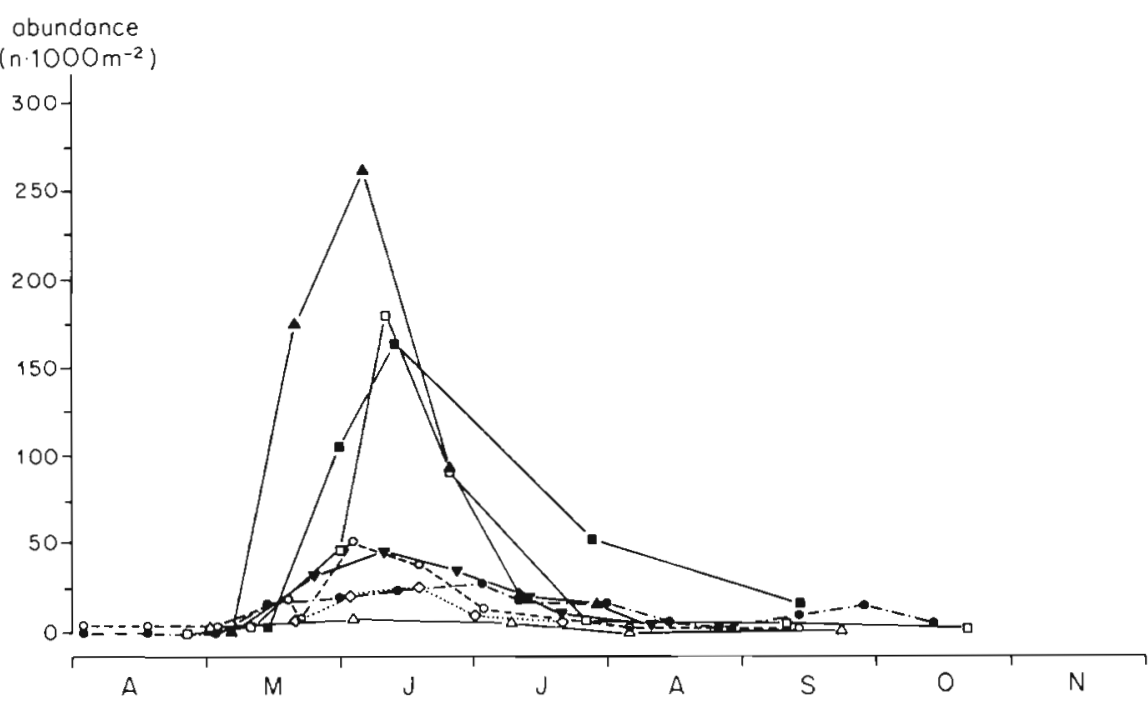




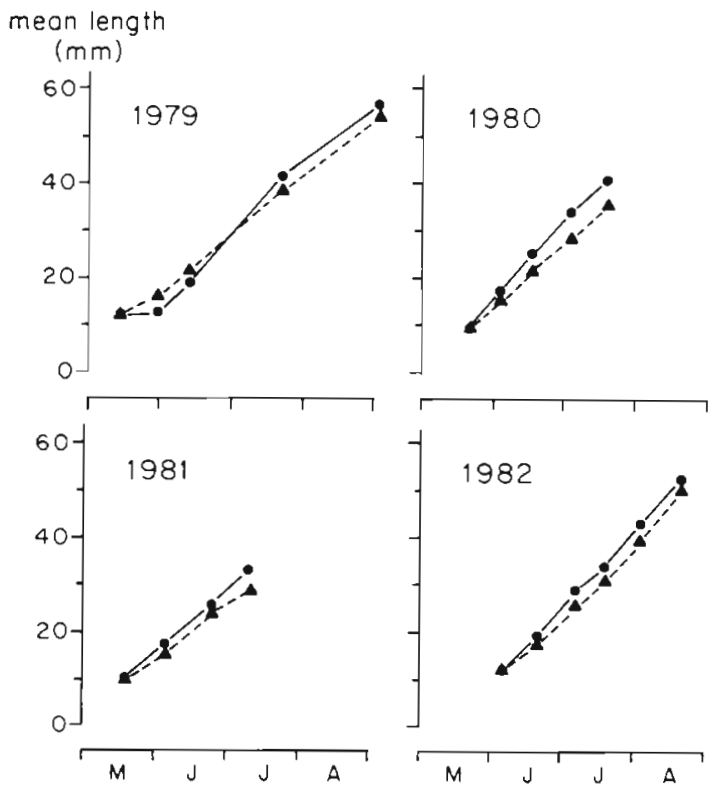

Fig. 3. Platichthys flesus. Observed increase length of 0 -group $(\mathrm{mm})$ flounder in the Balgzand compared with predicted maximum growth ( $-\mathbf{A}_{-\mathbf{4})}$ according to a growth model established under optimal food conditions in the laboratory (after Glazenburg 1983) for the years 1979 to 1982

mean abundance of 0 -group flounder in the Balgzand area. Only those sampling stations were taken into account where flounder were found, omitting the northernmost sandy stations. In all years considered, the first flounder were not observed until the middle of May, 1 mo after the arrival of the first planktonic larvae. Then, the population increased rapidly, reaching maximum densities in June. These peak values varied considerably, from $101000 \mathrm{~m}^{-2}$ in 1978 to $2671000 \mathrm{~m}^{-2}$ in 1981. From June onwards numbers declined, with only low densities after July.

In all years the size-frequency distribution was close to normal and therefore mean length has been estimated for the surveys of 1979 to 1982 (Fig. 3). The mean length in May when the first flounder were found varied from $9.6 \mathrm{~mm}$ in 1980 to $12.5 \mathrm{~mm}$ in 1981 In all years mean length showed a rapid increase from May onwards. The observed increase in mean length has been compared with a growth model obtained under excess feeding conditions in the laboratory, according to Glazenburg (1983):

$$
\Delta L=1.2 T-7.2\left(\mathrm{~mm} \mathrm{mo}^{-1}\right)
$$

in which $\Delta L=$ length increase in $\mathrm{mm} \mathrm{mo}^{-1}$; and $T=$ mean water temperature in ${ }^{\circ} \mathrm{C}$. Water temperatures were measured simultaneously with fishing (van der Veer 1986, van der Veer \& Groenewold 1987). From early May onwards there was a high similarity between observed and simulated lengths (Fig. 3), suggesting that growth of 0 -group flounder was not food-limited in the Balgzand area.

\section{Mortality}

The abundance of 0 -group flounder will be controlled by settlement, migration and mortality. As in 0 group plaice (Zijlstra et al. 1982), exchange with surrounding deep channels is negligible, because of the isolated location of the area. Due to the time lag between larval immigration and settlement at the Balgzand and the migration of settling larvae to the freshwater environment, the method used by van der Veer (1986) to estimate mortality between 2 successive surveys could not be applied to 0 -group flounder.

Instead of a mortality estimate for every $2 \mathrm{wk}$ period, the decrease between peak abundance in June and September was estimated for the different years according to:

$$
Z=1 / t \ln \left(N_{0} / N_{t}\right) \quad\left(\mathrm{d}^{-1}\right)
$$

in which $Z=$ instantaneous mortality rate $\left(\mathrm{d}^{-1}\right) ; t=$ time interval in days between June and September; and $N_{0}$ and $N_{t}$ are the abundance estimates at respectively $t_{0}$ (June) and $t_{\text {: }}$ (September). Relating the instantaneous mortality rate with the initial abundance resulted in a significant positive correlation between the two (Fig. 4) $\left(r_{s}=0.60 ; p<0.05\right)$. Since abundance and mortality are not independent variables, it cannot be excluded that part of the correlation originates from statistical effects. However, for 0-group plaice in the same area, an independent estimate of the relation between mortality and density showed that statistical effects were negligible (van der Veer 1986, van der Veer \& Bergman 1987).

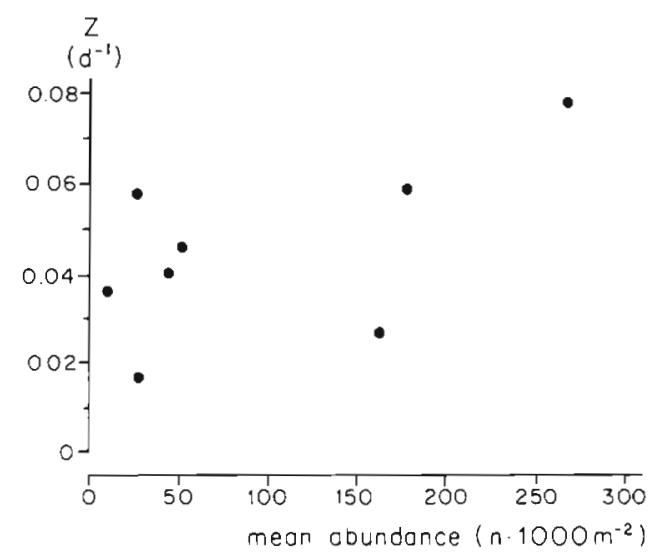

Fig. 4. Platichthys flesus. Daily instantaneous mortality rate $Z$ $\left(\mathrm{d}^{-1}\right)$ between peak abundance and 1 September in relation to density at peak abundance (n $1000 \mathrm{~m}^{-2}$ ) 
Table 2. Predation rate (n $12 \mathrm{~h}^{-1}$ ) of 10 shrimps Crangon crangon on 10 0-group flounder Platichthys flesus under experimental conditions in darkness at $18^{\circ} \mathrm{C}$. For more details see van der Veer \& Bergman (1987). Mean values of at least 3 replicates

\begin{tabular}{|ccc|}
\hline Shrimp size & \multicolumn{2}{c|}{ 0-group flounder } \\
& $16-20 \mathrm{~mm}$ & $31-35 \mathrm{~mm}$ \\
\hline $21-25 \mathrm{~mm}$ & 0 & 0 \\
$41-45 \mathrm{~mm}$ & 5 & 0 \\
$61-65 \mathrm{~mm}$ & 7 & 0 \\
\hline
\end{tabular}

The results of the predation experiments with Crangon crangon as predators are shown in Table 2. As in plaice, $C$. crangon was able to prey upon small 0-group flounder. The minimum size for shrimps to feed on 0 group flounder was between 25 and $41 \mathrm{~mm}$. Flounder larger than about $30 \mathrm{~mm}$ were no longer vulnerable to this type of predation. Fig. 5 shows the mean percentage of the 0-group flounder population with fin damage at high water at the Balgzand. In early June $65 \%$ of the population showed one or more points of fin damage. In June, this fraction decreased and from early July onwards no fin damage was found.

\section{DISCUSSION}

\section{Larval abundance, immigration and settlement}

The spawning grounds of flounder that supply the western Wadden Sea with larvae are located in the Southern Bight of the North Sea, as is the case for plaice

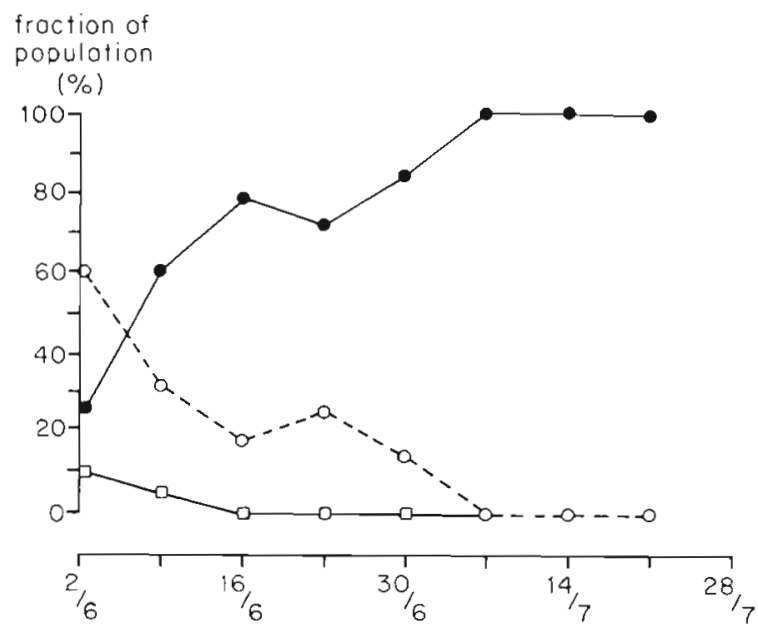

Fig. 5. Platichthys flesus. Mean percentage of 0-group flounder population at the Balgzand at high water in 1982 with respectively $0(-\bullet), 1(0--\infty)$ and 2 cases $(\square-\square)$ of fin damage $(n \geq 100)$ (see Houghton \& Harding 1976). No information is available on larval transport from the spawning grounds towards the coastal zone, but a similar process as in plaice is assumed: passive transport in the plankton by the residual currents in a northeasterly direction (Cushing 1990), followed by selective transport by tidal currents into the Wadden Sea, as found for plaice by Rijnsdorp et al. (1985) and Bergman et al. (1989). Inside the area they maintain their position by positive rheotaxis (Berghahn 1983). The immigration of flounder does not start until early April, i.e. 1 mo later than plaice (van der Veer 1985). In early May, the immigration of both plaice and flounder larvae is abruptly terminated by the outburst of predatory coelenterates such as the ctenophore Pleurobrachia pileus and the scyphomedusa Aurelia aurita (van der Veer 1985). This means that the process of larval immigration is restricted to about 1 mo in flounder, compared with about 2 mo in plaice. Nevertheless, every year the western Wadden Sea is supplied with more flounder than plaice larvae, because the shorter period of immigration is amply compensated for by a much higher abundance (van der Veer 1985).

Little is known about the process of larval settling. There are some laboratory observations suggesting that as in plaice the search for food by the hungry larvae is the key factor (Creutzberg et al. 1978). There is a timelag of about 1 mo between larval immigration and subsequent appearance in the demersal samples, which suggests that initial settling occurs in other areas. Before 1932, Lake IJssel, then known as the Zuiderzee, was still a major part of the western Wadden Sea where flounder could be found almost anywhere, even at very low salinities. Probably, initial settling of larval flounder still takes place in silty areas of low salinity close to the sluices where freshwater from Lake IJssel is discharged, as has been found by Berghahn (1984) in the German Wadden Sea and by Summers (1980) in a Scottish bay. After settlement an important part of the population is transported to Lake IJssel, as can be concluded from the high numbers found in fykes later in the year (Hortensius pers. comm.), and a part spreads out over the siltier tidal flats.

The relatively large size of the 0 -group flounder that appear on the Balgzand, compared with the larval size, suggests that migration movements at relatively small sizes already occurred shortly after settlement. After their appearance on the tidal flats, part of the population migrate with ebb tide to the tidal gully (van der Veer \& Groenewold 1987). The rest need about 4 to 6 wk to develop tidal migration movements, as do plaice (van der Veer \& Bergman 1986). It is unknown to what extent juvenile flounder suffer from the unsuitable environmental conditions of high temperatures and low oxygen concentrations on the tidal flats at low water in July-August (van der Veer \& Bergman 1987). 


\section{Demersal abundance}

The seasonal pattern of abundance of 0-group flounder resembles that of 0 -group plaice on the Balgzand (Zijlstra et al. 1982, van der Veer 1986): increasing densities up to a maximum, followed by a sharp decrease to low numbers during the rest of the year. The different timing of the larval immigration of flounder also results in a time-lag of about 1 mo between the peak densities of flounder and plaice: June vs May (van der Veer 1986), a period also observed in the German Wadden Sea (Berghahn 1987).

Although larval abundance of flounder exceeds that of plaice, densities of settled flounder are lower than those of plaice. 0-group plaice are found throughout the area, while 0 -group flounder are restricted to the siltier parts. In the areas sampled plaice are more abundant, mainly because of the migration of a major part of the larval flounder to fresh waters (Berghahn 1984).

If the general rule of decreasing mortality in fish with increasing size applies (Cushing 1974), flounder will be more vulnerable to predation than plaice during larval immigration (flounder $8 \mathrm{~mm}$; plaice $13 \mathrm{~mm}$ ). There are strong indications that flounder suffer heavy predation by coelenterates in the plankton (van der Veer 1985). As soon as the outburst of predatory coelenterates is observed in early May, immigration of both plaice and flounder ceases. After settlement, mortality among 0 group plaice is rather low, except for a short period directly after settlement, when a strong and densitydependent predation by crustaceans, mainly the brown shrimp Crangon crangon, is observed (van der Veer \& Bergman 1987). Plaice are preyed upon by shrimps until they reach a size of about $30 \mathrm{~mm}$ (van der Veer \& Bergman 1987). Because shrimps occur throughout the Balgzand area (Kuipers \& Dapper 1984), flounder also are believed to suffer this predation. Predation by shrimps can be assessed either by stomach content analysis of crustaceans, which is very time-consuming, or by examining the fins of flounder In plaice predation by shrimps was not always successful and unsuccessful predation attempts by shrimps resulted in characteristic patterns of fin damage (van der Veer \& Bergman 1987), which were also observed in flounder. Shrimps are able to prey upon flounder under laboratory conditions and presumably also in the field. Therefore, shrimp predation will also be a major mortality factor in 0-group flounder. Mortality due to food shortage does not seem likely, because in all years of observation length increases in the field were as large as predicted by a maximum growth model established under excess feeding conditions in the laboratory.

Mortality estimates among the 0-group flounder might be biased by migration of juvenile flounder to fresh water. However, the fact that in summer densities stabilized when the flounder had reached a size of $3 \mathrm{~cm}$ and were 'safe' from shrimp predation suggests that mortality is the main factor causing the decrease in numbers during summer. Mortality estimates among the 0-group flounder could not be calculated over biweekly periods as for 0-group plaice (van der Veer 1986), but only between the different years. In this way, the summer mortality between years was densitydependent, suggesting some regulation of the flounder population. This supports the observed reduction in between-year variation in abundance during summer. Mortality among flounder is about 3 times as high as among plaice. A comparison of mortality in various nurseries around the North Sea showed a relation between temperature and mortality in 0-group plaice (van der Veer et al. 1990). This could suggest that 0 group flounder also may suffer a higher mortality than 0-group plaice at Balgzand due to the higher water

Table 3. Platichthys flesus. Mean abundance during the larval (n $1000 \mathrm{~m}^{-3}$ ) and demersal stage (n $1000 \mathrm{~m}^{-2}$ ) together with the coefficient of variation (\%). Wadden Sea data are from the international Demersal Young Fish Surveys (DYFS), put at our disposal by Rijnsdorp, RIVO IJmuiden

\begin{tabular}{|c|c|c|c|}
\hline & Abundance & Coefficient of variation & No. of observations \\
\hline \multicolumn{4}{|l|}{ Pelagic stage } \\
\hline $\begin{array}{l}\text { Larval abundance near } \\
\text { Wadden Sea }\end{array}$ & 50.0 & 172 & 9 \\
\hline \multicolumn{4}{|l|}{ Demersal stage } \\
\hline $\begin{array}{l}\text { Year-class index of } 0 \text {-group } \\
\text { at Balgzand at settling }\end{array}$ & 95.6 & 99 & 8 \\
\hline $\begin{array}{l}\text { Year-class index of 0-group } \\
\text { at Balgzand in September }\end{array}$ & 6.2 & 80 & 8 \\
\hline $\begin{array}{l}\text { Year-class index of I-group } \\
\text { in Wadden Sea in spring }\end{array}$ & 1.14 & 80 & 12 \\
\hline
\end{tabular}


temperatures and the higher shrimp abundance (van der Veer \& Bergman 1987).

\section{Year-class strength determination}

Recruitment, defined as the number of juveniles joining the parent stock, can be studied by comparing estimates of abundance during various life stages over a number of years according to Beverton (1984) and van der Veer (1986). The trends in variability of these abundance estimates during the early life stages give an impression of periods of density-dependent and densityindependent mortality processes and of the period in which year-class strength is determined. Periods of density-dependent processes are characterized by a decrease in between-year variability between successive life stages. The period in which year-class strength is determined is characterized by the fact that from that moment onwards, abundance estimates of that life stage are related to the ultimate recruitment (van der Veer 1986), and in plaice this period corresponds also with maximum variability between years (van der Veer 1986).

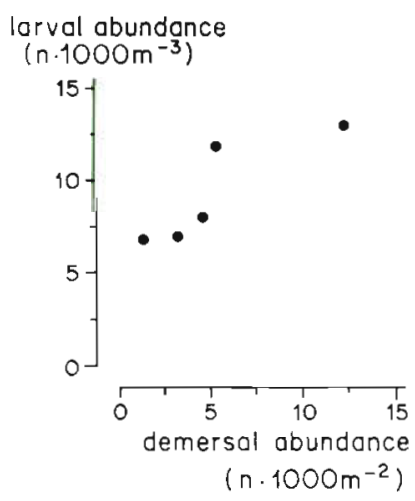

Fig. 6. Platichthys flesus. Relationship between abundance of settled 0-group flounder (n $1000 \mathrm{~m}^{-2}$ ) in August on the Balgzand and mean larval flood abundance (n $1000 \mathrm{~m}^{-3}$ )

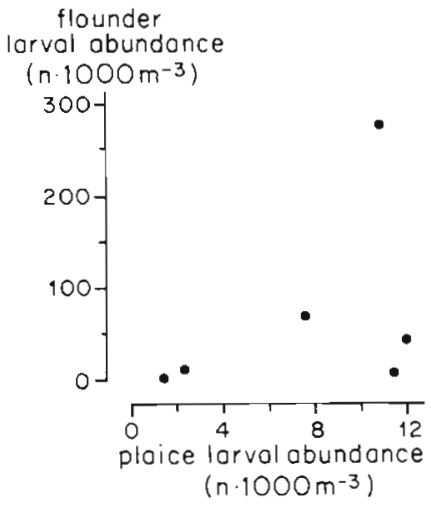

Fig. 7. Relation between mean larval flood abundance of plaice and flounder (n $1000 \mathrm{~m}^{-3}$ )
Table 3 shows estimates of mean abundance at various life stages of 0-group flounder together with an index of variability between years, the coefficient of variation, defined as standard deviation divided by the mean as percentage. This coefficient measures the relative dispersion, independent of the units. The pattern in the year-to-year variation during early life phases of 0 -group flounder appears to be similar to that in 0-group plaice (van der Veer 1986): a decrease in variation from the pelagic egg and larval stages until autumn, suggesting some density-dependent regulation during this period. No information is available on the adult spawning stock. However, in plaice this variation remains the same after the first year of life (van der Veer 1986). Assuming the same for flounder, this would mean an annual variability in spawning stock biomass of about $80 \%$. In comparison with a coefficient of variation of $170 \%$ during larval immigration, this suggests that the year-class strength of flounder is generated during the pelagic egg or larval stages, as in plaice (van der Veer 1986). This is further supported by the significant relationship $\left(r_{s}=1.0 ; p<0.05\right)$ between mean larval flood tide abundance and density of 0-group flounder in August (Fig. 6). In plaice a much lower year-to-year variability in year-class strength during the pelagic stages has been generated, about $60 \%$ (van der Veer 1986) compared with $170 \%$ in flounder. There is no explanation for this difference.

In conclusion, 0-group flounder and plaice have a similar life history. In both species year-class strength is generated during the pelagic stages, but the year-class strength of plaice and flounder shows no relationship (Fig. 7) $\left(\mathrm{r}_{\mathrm{s}}=0.37 ; \mathrm{ns}\right)$. After settlement of flounder some regulation of the population seems to occur, most probably caused by shrimp predation, as in plaice. Despite the concentration of high numbers in a relatively small area, growth conditions always were optimal. Differences between the 2 species might be attributed to a different timing in spawning and larval arrival in the nursery.

Acknowledgements. Thanks are due to F. Creutzberg and A. D. Rijnsdorp for putting their unpublished flounder data at our disposal. The manuscript was improved by the comments of $R$. Berghahn and the anonymous reviewers. Publication no. 21 of the project 'Applied Scientific Research Netherlands Institute for Sea Research (BEWON)'.

\section{LITERATURE CITED}

Berghahn, R. (1983). Untersuchungen an Plattfischen und Nordseegarnelen (Crangon crangon) im Eulitoral des Wattenmeeres nach dem Übergang zum Bodenleben. Helgoländer Meeresunters. 36: 163-181

Berghahn, R. (1984). Zeitliche und räumliche Koexistenz ausgewählter Fisch- und Krebsarten im Wattenmeer und 
Berücksichtigung von Räuber-Beute-Beziehungen und Nahrungskonkurrenz. Thesis, Univ. of Hamburg

Berghahn, R. (1987). The Wadden Sea as a nursery for fish and crustacean species. Fiskeri- og Sofartsmuseet Saltvandsakvariets Biologiske Meddelser 31: 69-85

Bergman, M. J. N., Stam, A., Veer, H. W. van der (1987). Abundance and growth of 0 -group plaice (Pleuronectes platessa L.) in relation to food abundance in a coastal nursery area. Comm. Meet. int. Coun. Explor. Sea C.M.ICES/L: 10: 1-9

Bergman, M. J. N., Veer, H. W. van der, Stam, A., Zuidema, D. (1989). Transport mechanisms of larval plaice (Pleuronectes platessa $\mathrm{L}$.) from the coastal zone into the Wadden Sea nursery area. Rapp. P.-v. Réun. Cons. int. Explor. Mer 191 $43-49$

Bergman, M. J. N., Veer, H. W. van der, Zijlstra, J. J. (1988) Plaice nurseries: effects on recruitment. J. Fish. Biol (Suppl. A) 33: 201-218

Beverton, R. J. H. (1984). Dynamics of single species. In: May, R. M. (ed.) Exploitation of marine communities. Life sciences Research Report 32. Springer-Verlag, Berlin p. $13-58$

Creutzberg, F., Eltink, A. Th. G. W., Noort, G. J. van (1978) The migration of plaice larvae Pleuronectes platessa into the western Wadden Sea. In: McLusky, D. S., Berry, A. J (eds.) Physiology and behaviour of marine organisms. Proc. 12th Europ. mar. biol. Symp. Pergamon Press, Oxford, p. 243-251

Cushing, D. H. (1974). The possible density-dependence of larval mortality and adult mortality in fishes. In: Blaxter, $\mathrm{J}$. H. S. (ed.) The early life history of fish. Springer-Verlag, Berlin, p. 103-112

Cushing, D. H. (1990). Hydrographic containment of a spawning group of plaice in the Southern Bight of the North Sea. Mar. Ecol. Prog. Ser. 58: 287-297

Dapper, R. (1978). De Balgzand scholgegevens 1975, 1976 , 1977. Interne Verslagen Nederlands Instituut voor Onderzoek der Zee, Texel, 1978-12: 1-53

Dapper, R., Veer, H. W van der (1981). Onderzoek naar de ruimtelijke variatie van de bodemsamenstelling op het Balgzand. Interne Verslagen Nederlands Instituut voor Onderzoek der Zee, Texel, 1981-9: 1-21

Elliot, J. M. (1971). Some methods for the statistical analysis of samples of benthic invertebrates. Freshwater Biological Association, Scientific Publications No. 25, Ambleside: 1-160

Glazenburg, B. (1983). Een experimenteel onderzoek naar de groei van 0 -groep schol en bot in relatie tot de watertemperatuur Interne Verslagen Nederlands Instituut voor Onderzoek der Zee, Texel, 1983-5: 1-19

Harding, D., Nicols J. H., Tungate, D. S. (1978). The spawning of the plaice (Pleuronectes platessa) in the southern North Sea and English Channel. Rapp. P.-v. Réun. Cons. int. Explor. Mer 172: 261-296

Houghton, R. G., Harding, D. (1976). The plaice of the English Channel. spawning and migration. J Cons. int. Explor Mer 36: 229-239

Kuipers, B. R. (1973). On the tidal migration of young plaice (Pleuronectes platessa) in the Wadden Sea. Neth. J. Sea Res. 6: 69-85

Kuipers, B. R. (1975). On the efficiency of a two meter beam trawl in juvenile plaice. Neth. J. Sea Res. 9: 65-85
Kuipers, B. R. (1977). On the ecology of juvenile plaice on a tidal flat in the Wadden Sea. Neth. $J$. Sea Res. 11: 59-91

Kuipers, B. R., Dapper, R. (1984). Nursery function of Wadden Sea tidal flats for the brown shrimp Crangon crangon. Mar. Ecol. Prog. Ser. 17: 171-181

Rauck, G., Zijlstra, J. J. (1978). On the nursery aspects of the Wadden Sea for some commercial fish species and possible long-term changes. Rapp. P.-v. Réun. Cons. int. Explor. Mer 172: 266-275

Riley, J. D., Corlett, J. (1966). The numbers of 0-group plaice in Port Erin Bay 1964-66. Rep. mar biol. Stn Port Erin 78: 51-56

Rijnsdorp, A. D., Stralen, M. van, Veer, H. W. van der (1985). Selective tidal transport of North Sea plaice Pleuronectes platessa in coastal nursery areas. Trans. Am. Fish. Soc. 114: $461-470$

Smith, P. E., Counts, R. C., Clutter, R. I. (1968). Changes in filtering efficiency of plankton nets due to clogging under tow. J. Cons. perm. int. Explor. Mer 32: 232-248

Summers, R. W. (1980). Life cycle and population ecology of the flounder (Paralichthys flesus L.) in the Ythan estuary, Scotland. J. nat. Hist. 13: 703-723

Veer, H. W van der (1985). Impact of coelenterate predation on larval plaice Pleuronectes platessa and flounder Platichthys flesus stock in the western Wadden Sea. Mar Ecol. Prog. Ser. 25: 229-238

Veer, H. W. van der (1986). Immigration, settlement, and density-dependent mortality of a larval and early postlarval 0-group plaice (Pleuronectes platessa) population in the western Wadden Sea. Mar. Ecol. Prog. Ser 29: 223-236

Veer, H. W. van der, Bergman, M. J. N. (1986). Development of tidally related behaviour of a newly-settled 0-group plaice (Pleuronectes platessa L.) population in the western Wadden Sea. Mar. Ecol. Prog. Ser. 31. 121-129

Veer, H. W. van der, Bergman, M. J. N. (1987). Predation by crustaceans on a newly settled 0-group plaice Pleuronectes platessa population in the western Wadden Sea. Mar. Ecol. Prog. Ser 35: 203-215

Veer, H. W. van der, Groenewold, A. (1987). The ecology of 0 group flounder (Platichthys flesus L.) in the western Wadden Sea. Comm. Meet. int. Coun. Explor. Sea C.M.-ICES/ L: $41: 9 \mathrm{pp}$

Veer, H. W van der, Pihl, L., Bergman, M. J. N. (1990). Recruitment mechanisms in North Sea plaice Pleuronectes platessa. Mar. Ecol. Prog. Ser 64: 1-12

Vlas, J. de (1979). Annual food intake by plaice and flounder in a tidal flat area in the Dutch Wadden Sea with special reference to consumption of regenerating parts of macrobenthic prey. Neth. J. Sea Res. 13: 117-153

Zijlstra, J. J. (1972). On the importance of the Wadden Sea as a nursery area in relation to the conservation of the southern North Sea fishery resources. Symp. zool. Soc. Lond. 29: $233-258$

Zijlstra, J. J., Dapper, R., Witte, J. J.J. (1982). Settlement, growth and mortality of post-larval plaice (Pleuronectes platessa L.) in the western Wadden Sea. Neth. J. Sea Res. 15: $250-272$

Zijlstra, J. J., Witte, J. IJ. (1985). On the recruitment of 0-group plaice in the North Sea. Neth. J. Zool. 35: 360-376

Manuscript first received: July 13,1990

Revised version accepted: April 15, 1991

This article was submitted to the editor 